\title{
The impact of rock climbing on the micro-relief of sandstone surfaces: The case study of the Carpathian tors
}

\author{
Polish Academy of Sciences, Institute of Nature Conservation, al. A. Mickiewicza 33, 31-120 Krakow, Poland; *Corresponding author, \\ E-mail: alexandrowicz@iop.krakow.pl
}

(Received: April 9, 2015; Revised accepted: November 3, 2015)

http://dx.doi.org/10.18814/epiiugs/2017/v40i1/017009

The aim of the article is the proof of the small resistance of Carpathian sandstone tors on the activity of climbers. The threats to rock sites, and the damage caused by climbing, particularly to their natural relief, have only occasionally been recorded and studied. In this paper, the issue was considered regarding protected tors made of the thickbedded sandstone-conglomerate complexes occurring in the Outer (Flysch) Polish Carpathians. Carpathian tors, particularly those which are small in size with walls that feature diversified morphology, have become particularly frequent sites for bouldering. The assessment of the effects of rock climbing was based on the author's earlier research concerning the preservation and origin of sandstone tors, thermo-humidity regime of their surfaces, as well as the creation and transformation of the weathering crust. Rock climbing activities result not only in the damage and destruction of micro-relief of tors, but they also speed up and disturb the course of natural weathering processes by forcing the exfoliation of the crust and intensifying the granular disintegration of sandstones. Irrespective of the protection status of natural rock forms, various kinds of climbing on them should be considered unethical, in the same way as painting graffiti or drilling to take samples. Within the promoted idea of geoethical education, a wide range of current and forecasted threats to the values of natural geological heritage should be considered.

\section{Introduction}

The surfaces of rock formations are exposed by the action of natural processes. They constitute unusually attractive components of landscapes in various climatic zones, lending peculiar beauty to them. They assist both the development of tourism and also various kinds of climbing sports. Usually, such uses are associated with economic benefits but also with threats to the environment and nature. As a consequence of the increasingly visible and documented results of excessive tourist activities, restrictions have been introduced but they do not solve this ever deepening problem (Giuliano, 1994). This particularly affects the most beautiful and accessible mountain regions, covered by protec- tion under various categories of national and international schemes. In order to counteract the threats, the locations occupied by rare species of epilithic plants, as well as sites where rare animals nest and shelter, are often secured by protective measures. It is only on rare occasions that these measures are designed to prevent the progress in devastation of rock surfaces and their micro-forms caused by the sport of climbing, despite the fact that this types of damage are directly affecting the flora and fauna (Robinson and Williams, 2005; Robinson, 2007; Williams, 2007; Jodłowski, 2011; Alexandrowicz, 2014).

Over the past two decades, climbing has become ever more popular on natural moderately high sandstone rock faces which are considered the most suitable for a form of climbing called bouldering (Jodłowski, 2011). It consists of negotiating the rock wall from its base to the height of several metres without using safety gear but applying adhesion-improving agents, using the natural unevenness of the rock face and sometimes even artificially deepening or carving steps. These damages are being monitored on walls of numerous sandstone tors in the Carpathian Mts. One of the most frequently visited bouldering sites is the Forest of Fontainebleau near Paris, protected within a UNESCO Biosphere Reserve (Čeřovský, 2007; Jodłowski, 2011). The experience gathered there was used to develop the scale of difficulty in this sport, called the Fontainebleau scale - abbreviated as Font.

To date, there has been an insufficient amount of monitoring data that could be used to evaluate the rate and extent of damage to the relief of sandstone tors due to climbing. Photographic documentation which enables comparisons between the past and present state can be particularly useful for this purpose. From this, we can principally learn about the progressing and excessive succession of plants overshadowing the tors, as well as their fragments which fall off, are lost or are damaged by climbers. Known instrumental methods for long-term measurements (e.g., photogrammetry and micro-mapping) of weathered rock surfaces, have not yet been applied in the case of damage from climbing (Williams et al., 2000; Moses et al., 2014).

According to Polish legislation climbing on rocks protected as nature monuments as well as situated in nature reserves and in national parks is not allowed. However this regulation is not obligatory in landscape parks and areas of protected landscape so that a lot of valuable and interesting rocky forms stay still outside protection. For all that in the Flysch Carpathians, climbing activities, particularly bouldering, are pursued in 55 localities with c. 1000 climbing routes (Jodłowski, 2011). These are mostly situated in all nine existing rock reserves, as well as 


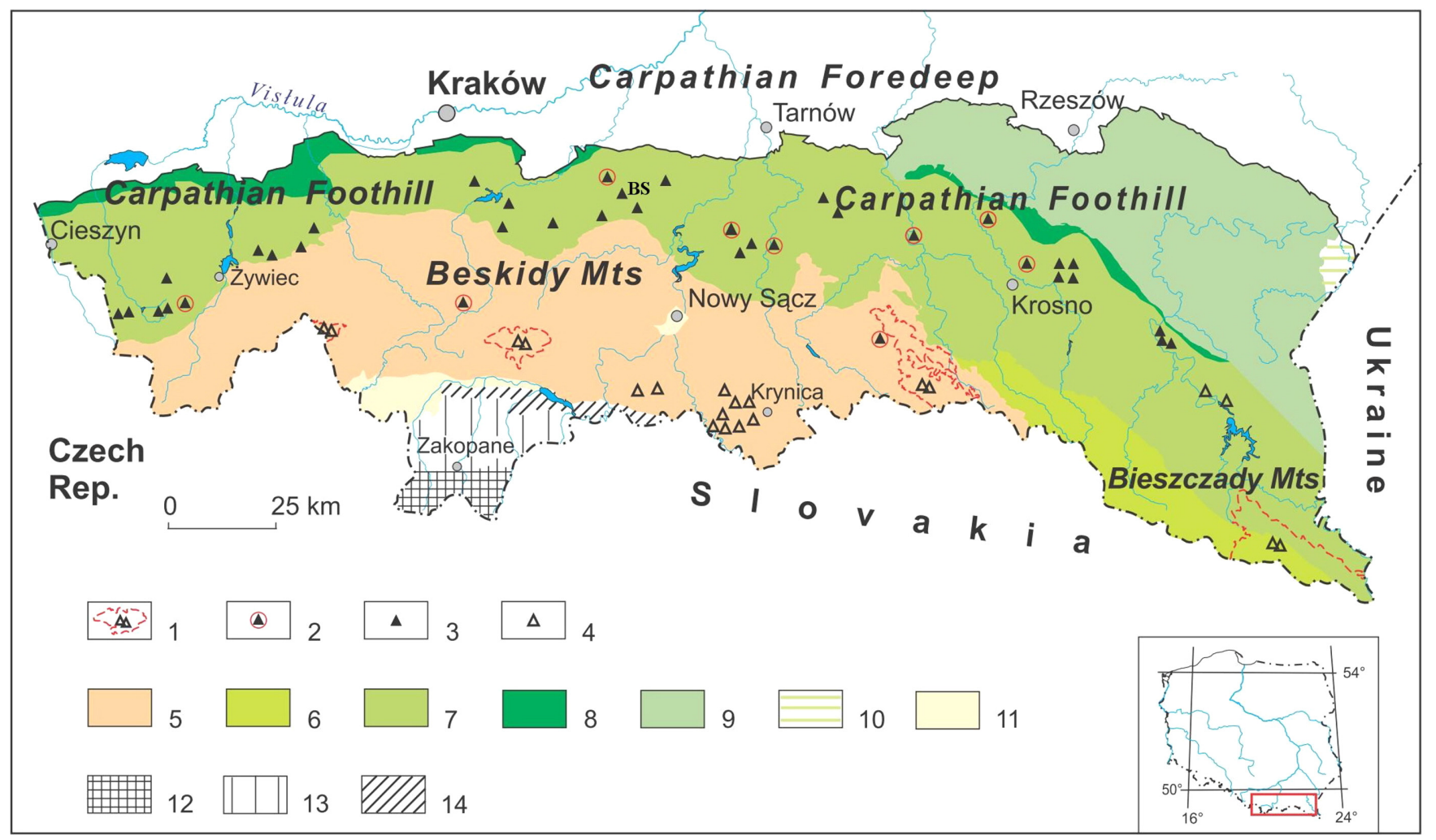

Figure 1. Distribution of protected sandstone rocky forms in relations to climbing activity (after Alexandrowicz and Poprawa (eds.), 2000, supplemented; Jodlowski, 2011) on the main geological structures of the Polish Outer (Flysch) Carpathians and Central Carpathians (after Żytko et al., 1988-1989): 1 - national parks with rocky forms without climbing, 2 - nature reserves with rocky forms occupied by climbing, 3 - rocky forms as nature monuments occupied by climbing, 4 - rocky forms as nature monuments without climbing, 5-Magura Unit, 6 - Dukla U., 7Silesian U., 8-Subsilesian U., 9-Skole U., 10-Stebnik Stebnik U., 11 -Neogene deposites on flysch, 12 - Tatra Mts, 13 -Podhale Flysch, 14 Pieniny Klippen Belt, BS - Nature Monument Brodziński Stones.

within 28 of the 40 protected nature monuments of this type (Alexandrowicz, 1978; Alexandrowicz and Poprawa, 2000; Alexandrowicz and Urban, 2005) (Fig. 1). These objects are easily accessible and offer diversified relief. In particular localities, the number of registered climbing routes range from several to twenty or so. In 2011, in some areas of rock reserves, several hundred passages were recorded. Perhaps the data pertaining to these activities (number of passages) is understated compared to the real numbers due to the limited restrictions imposed on climbers and their movements. Sometimes, rocky sites in as many as four national parks in a given area are used.

The long-term observation and multi-directional studies of sandstone tors occurring in the Polish Outer (Flysch) Carpathians provide sufficient data to explain the causes, courses, and outcomes of the destructive effects of climbing on the morphology of tor surfaces. The results, which are interesting from the viewpoint of the presented topics, principally pertain to the recording of threats and the protection status of the tors occurring there, as well as the thermo-humidity regime of rock surfaces, and the origin and transformation of their natural protective weathering crust.

\section{Outline of geological setting and origin of sandstone forms in the Polish Carpathians}

The Polish Outer (Flysch) Carpathians are the northernmost part of the Carpathian Mountains. They consist chiefly of middle mountain ranges (800-1300 $\mathrm{m}$ a.s.l.) with its highest summit - Babia Góra (1725 $\mathrm{m}$ a.s.1.), intra-mountain basins, and foothills in the northern foreland area. The flysch formations of the Late Jurassic - Early Miocene age, developed as alternating variably-thick beds of sandstones, mudstones and shales, occasionally marls and hornstones, as well as thick-bedded sandstone-conglomerate complexes. Natural rocky forms occur on ridges, in upper parts of mountain slopes, and within the valley-sides. They are built by sandstone-conglomerate formations, classified to various lithostratigraphic units (Alexandrowicz, 1970, 1978). The sequences of these forms occur within nappes thrust over each other horizontally towards the north (Książkiewicz, 1972; Żytko et al., 1989; Oszczypko, 2006) (Fig. 1).

Natural sandstone exposures, particularly within the area of the Carpathian Foothill, show specific lithological, tectonic, and sedimentary features. These are formations of flysch composed mainly of thick-bedded, coarse-grained sandstones and conglomerates with a rare network of joints. They are composed of quartz grains with an admixture of feldspar, glauconite and muscovite. Sandstones are poorly sorted, with irregularly distributed cement, usually argillaceous, argillaceousferruginous, and more rarely calcareous-argillaceous, calcareous or matrix comprising fine clastic-clayey sediment. Conglomerates, apart from quartz, contain pebbles of hornstones, granites, metamorphic schists and other exotics of the pre-Carpathian origin. Particular complexes of thick beds are separated by thin-bedded shale-sandstone flysch. 
Somewhere within the coarse grained beds, clay balls and ferruginous concretions are found. Rock beds show specific features in the form of various bedding and traces of erosion testifying to the sediments deposition processes in a deep-sea environment. The thick-bedded coarse-grained complexes and differentiated sedimentary structures are characteristic of the fluxoturbidites deposited by submarine sliding as mud/sand/gravel debris flows (Unrug, 1963; Ślączka and Thompson, 1981; Leszczyński, 1989).

Because of their considerable thickness, the sandstone-conglomerate complexes became exposed in the relief of the Flysch Carpathians during their formation. The segmentation of rock massifs occurred along joints which underwent opening and turned into cracks. Particularly favorable conditions for the development of this process prevailed when long-term permafrost disappeared towards the end of the last glaciation in the Pleistocene (Alexandrowicz, 1977, 1978). At first, the gravitational disintegration of the originally compact rock massif had not been of the sliding type where packets separate from the substrate and move along a slope. The separating of rock forms followed during the gradually subsidence of the massif, divided along broaden joints and open fissures (Dikau et al., 1996).

The relaxation of conglomerate-sandstone complexes affected by retreating permafrost, their flysch clayey-sandy substrate, and the erosive deepening of valleys, markedly favoured the development of mass movements. In the Pleistocene and Holocene, intensively initiated relief-formation processes led to the lowering of the summit surfaces and the withdrawing of slopes (Baumgart-Kotarba, 1974). Within them, relatively more resistant, concretionary, and naturally exposed fragments of rocks were ultimately shaped by the processes of selective weathering into original forms occurring in situ chiefly in the Carpathian Foothill, or - relocated by the mass movements of various intensities - on steep slopes of the Outer (Flysch) Carpathians in Beskidy Mts and Bieszczady Mts (e.g., Lach, 1970; Alexandrowicz, 1978; Margielewski, 2006; Alexandrowicz and Margielewski, 2010). At present, despite the continuous transformation of natural outcrops, an evident link can be observed in numerous places between the morphology of walls and open fissures, and the running planes of joints.

\section{Damaging of weathering micro-relief caused by climbing}

The elements of relief occurring on exposed surfaces of sandstones are called weathering micro-forms or weathering micro-relief, whereas in the classification proposed by A.V. Turkington and T.R. Paradise (2005) they are included in the group of small-scale forms. Chemical, physical, and biological weathering processes participate in developing these forms. The effects of these processes depend on the lithology, mineralogical composition, as well as on the sedimentary and structural properties of the sandstones. The diversity of micro-forms indicates relationships between different weathering processes of rocks. Similarly developed weathering forms occur in various climatic zones and in a wide spectrum of rock types (e.g., Wilhelmy, 1958; Wiśniewski, 1983; Robinson and Williams, 1994; Adamovič et al., 2000; Mikuláš, 2007a; Goudie and Viles, 2008). It testifies to their polygenic origin. During more than 170 years of observations, fascination, and descriptions of these forms, various names have emerged (e.g., Mustoe, 1982; Turking- ton and Paradise, 2005; Mikuláš, 2007b; Robinson, 2007).

Typical relief elements on the surfaces of Carpathian tors are thin ribs of relatively hard, cemented sandstone protruding from the walls, as well as the cavernous structures of different types and origins, referred to by many different names (Świdziński, 1933; Klimaszewski, 1932, 1947; Koszarski, 1962; Alexandrowicz, 1970; 1978, 2008; Kicińska, 2009; Strzeboński, 2009). The mentioned relief of sandstone walls is particularly characteristic for lithologically diversified small rock forms, usually five to eight metres high, rarely exceeding ten metres. Compared to these, the high rock walls, usually connected with landslides, are less modelled and clearly limited by planes of joints.

The principal objective of protecting the micro-relief of sandstone surfaces is to guarantee their natural course of further evolution under the existing climatic conditions. Climbing activities are currently one of the factors making this task more difficult. Examinations of technical (physical) properties of Carpathian sandstones where tors occur, revealed their low cohesiveness and remarkable porosity compared to other types of sandstone in the area (Bromowicz et al., 1976). The sandstones of tors usually show fairly low apparent density not exceeding the value of $2.6 \mathrm{~g} / \mathrm{cm}^{3}$. They also have relatively high water absorption with their mean value in the range of $2-8 \%$ (Alexandrowicz, 1978). Despite their unfavourable physical properties, they have remained in mountain landscapes as relatively resistant fragments, exposed among different lithological types of thick sandstone complexes.

\section{Thermo-humidity regime of rock surfaces}

Depending on the prevailing meteorological (weather) conditions, rock surfaces undergo variable cycles of warming and cooling, as well as humidifying and drying. To date, the specific conditions of microclimates which occur in the contact zone are only little studied (Turkington and Paradise, 2005). The great majority of such data has been collected in areas where climate shows large amplitudes of daily and seasonal temperatures (Hall, 1997; Lewkowicz, 2001). However, in relation to the growing sport of climbing, particularly in areas with sandstone tors that are especially vulnerable to degradation caused by climbing, these types of measurements are essential indicators of the potential dangers to the micro-relief of rock surfaces. This statement is emphatically supported by the measurements of temperature and humidity taken at 28 points located at different levels of height and exposure, conducted on two selected Carpathian sandstone tors differing in their shape and location with respect to the surrounding elements of land morphology (Alexandrowicz and Brzeźniak, 1989). The published data was obtained in ten cycles of measurements in one-hour (temperature) or two-hour intervals (humidity) throughout $24 \mathrm{hrs}$ or only during the day in the summer from 1982 to 1986, in different weather conditions, as well as in a single cycle during winter (1983). The measurements were taken with the use of Assmann aspiration psychrometers, and purpose-made analogue thermometers with adhesive pads and semiconductor sensors. The weather conditions were also monitored throughout the measurements. Checking measurements led occasionally in later years didn't contribute essential corrections.

The regularities found in the distribution of the measured thermohumidity parameters made it possible to evaluate their effect on the development of weathering processes in particular height-zones of the tor profile. In the warm seasons of the year, the lower portion of the 
tor wall, up to the height of $2 \mathrm{~m}$, has - irrespective of the wall exposure the lowest temperature over $24 \mathrm{hrs}$, and the highest humidity, the latter coming chiefly from the capillary drawing of water from the substrate. The amplitudes of temperature and humidity between day and night are relatively the lowest there compared to the whole profile of the tor, and the temperatures in the day during the winter are the highest. In the higher part of the tor profile, there is a clear increase in surface temperature coupled with a simultaneously decreasing humidity, coming chiefly from atmospheric precipitation and the condensation of water vapour. The phenomena of humidifying and drying up the rock surface is repeated a number of times. In the highest part of the tor profile, the highest fluctuations in temperature and humidity occur over 24 hrs. The changeability of weather conditions within the 24-hour period manifests itself in particular portions of the tor profile principally in the diversification of amplitudes of the measured parameters.

\section{Rock thermo-humidity and their implications for weathering}

The natural protective layer, irregularly covering the surfaces of Carpathian tors, consists of a hard weathering crust, usually $1-2 \mathrm{~cm}$ thick, and - more rarely - several centimetres thick (Alexandrowicz and Pawlikowski, 1982; Rzepa et al., 2011; Alexandrowicz et al., 2012, 2014; Marszałek et al., 2012). It is composed of very thin laminae, macroscopically differing in colour, running either as a continual or broken layer, in parallel to the rock surface. This crust is a transformed zone of sandstone where pores were partly filled up by secondary minerals originating from the chemical decomposition rock and the migration of dissolved components towards the surface. The hardened zone is enriched chiefly with goethite, hematite, and amorphous silica. The iron contents are responsible for the diversified colouration of the weathering crust, and its hardness depends above all on the occurrence of amorphous silica. Also essential is the role played by the outer, black lamina which emerged as a result of air pollution, composed principally of sulphate incrustations and containing organic particles. The transformation of the mineralogical composition of the surface zone of sandstone walls caused by weathering agents proceeds very slowly, compared with the rate of this process in the architectural historic details (Wilczyńska-Michalik, 2004; Marszałek et al., 2014). In natural conditions, it enables the successive regeneration of damaged surfaces by developing a new protective crust. The weathering crust and co-existing weathering micro-forms are at a different stage of development, thus testifying to the continuity and progress of the process of transformation of the rock surface (e.g., Robinson and Williams, 1994; Cílek, 1997; Turkington and Paradise, 2005; Mikuláš, 2007b; Robinson, 2007; Alexandrowicz et al., 2014). The measurements demonstrated that the particular height-zones of the tors showed differences in the thermo-humidity regime of the exposed surfaces (Alexandrowicz and Brzeźniak, 1989). Apart from the lithology and porosity of the sandstone, this regime has a major influence on the diversification of the cementation of tors' surfaces and developing micro-forms within them. In the lower portions of tor walls, the crust is mostly poorly and fragmentarily developed. The humidification prevailing there, either permanent or periodical, favours both the strong effect of frost action and salt weathering. The progress of these processes leads to granular disintegration, and the exfoliation of sandstones, resulting in the rapid destruction of lower parts of tors. It chiefly per- tains to the wall exposed toward the north and south which are characterized by the largest contrasts in the values of humidity and temperatures measured over 24 hrs. Furthermore, the rock walls maintaining permanent humidity are easily colonized by mosses, and the humic acids produced in their biochemical decomposition largely accelerate the weathering of sandstones. The intensive processes proceeding at the tor bases can lead to creating variably-sized niches, unstable overhangs, and narrowings giving the tors mushroom-like shapes.

Within the higher parts of tor walls, well-developed crusts with diversified weathering forms usually occur. This zone is subject to the frequent moistening and drying of the sandstone. With the passage of time, the cyclically repeated heating of the surface during the day and its cooling at night leads to the exfoliating and dropping of thick weathering crusts developed on poorly cemented sandstone. In the top parts of tors there is a phenomenon of most frequent cycling of rock temperatures through $0{ }^{\circ} \mathrm{C}$ which increases the local effectiveness of frost action. Stresses occur in the rock, which contribute to its segmentation along joints, and the horizontal stratification of beds. The environmental conditions on an uneven top surface favour the development of weathering pits having specific seasonal developmental cycles, dependent entirely on atmospheric precipitation and air temperature (Alexandrowicz, 1989).

\section{Destructive effects of rock climbing}

Climbing activities pursued on exposed sandstone walls result in accelerating and disturbing the course of natural processes of their weathering. On climbing routes, the morphology of rock walls is successively destroyed as a result of the forced exfoliation of the protective crust as well as of co-occurring weathering micro-forms and - as a consequence - the intensive disintegration of exposed, poorly cemented sandstone. The frequent manner of climbing on marked routes excludes entirely the regeneration of the weathering crust in such places. Its destruction prompts climbers to mark new, more suitable and more attractive routes for climbing.

The bouldering-type of climbing, increasingly often pursued on sandstone tors, is particularly destructive. Chosen of this an example is the Nature Monument "Brodziński Stones" situated in the middle part of Carpathian Foothill (Fig. 1 - BS), particularly the relatively large and effective rocky form called "Ship" (Fig. 2a). Different kinds of the degradation of rock faces can be observed here. In particular, it involves destroying the lower fragments of walls which are subject to particularly adverse micro-climatic conditions in any season of the year. In strongly overhanging places, rock falls are most numerous. The platforms and thresholds occurring at the tor bases which are initial parts of climbing bear the risk of permanent destruction. Bouldering with the aid of magnesia (hydrated magnesium bicarbonate) leaves unaesthetic white stains not washable by rain (Fig. 2b). Many climbing routes are permanently marked with coloured oil paints and engraved inscriptions (Fig. 2c), or - at some places - facilitated by carved thresholds. Various substances facilitating climbing result in the local sealing of the sandstone surface, thus hindering the free vaporization of moisture. In such conditions, the rate of increase of the weathering crust not yet completely destroyed, is markedly slowed down. The occasionally used mechanical removal of stains by scratching, forces their exfoliation, and the exposed sandstone poor in cement undergoes 

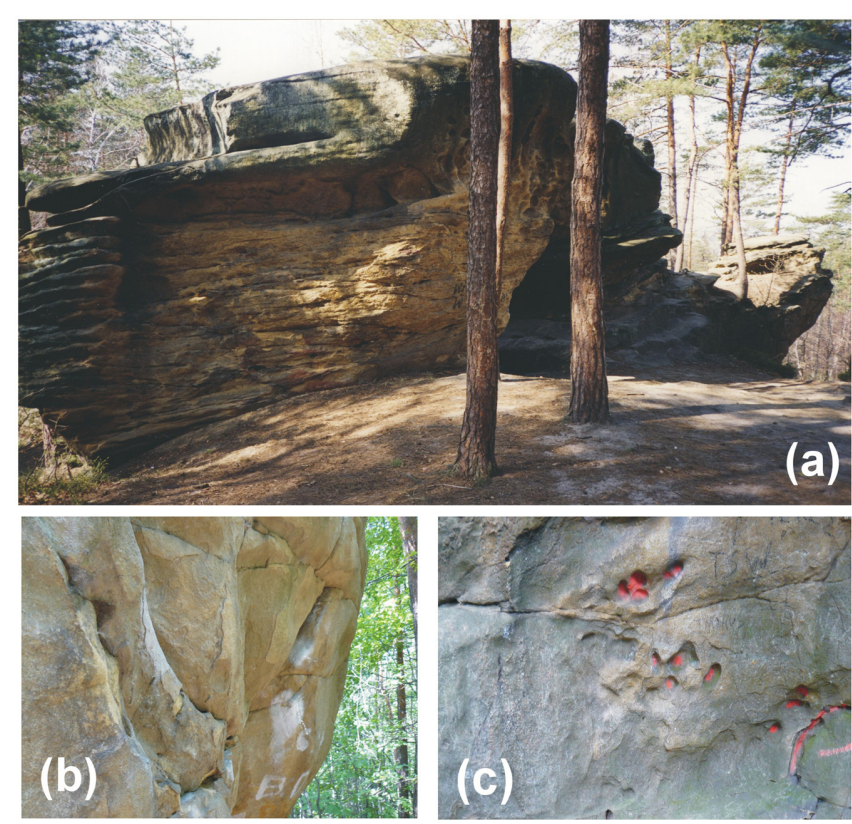

Figure 2. Trace markers of climbing (bouldering) activity on walls of the rock called "Ship" (Nature Monument Brodzin'ski Stones) in the Polish Carpathian Foothill (Fig. 1-BS): (a) the rock "Ship" (view from $S E$ ), the relief reflects differentiation of lithology and sedimentary structures of the Istebna Sandstone Formation, numerous traces of destruction and exfoliation of weathering crust in the lower part of the tor; (b) damages to weathering crust along the route of bouldering marked by white magnesium on fissured rock corner at risk of fall of; (c) fragment of wall with natural cavities marked by red oil paint on the climbing route.

intensified disintegration. The protective crust is destroyed by climbing on the whole height of the wall when the former uses various permanent installations or impermanent safety points.

\section{Final remarks}

In view of the increasing popularity of climbing activities on natural rock walls, and the application of newer and newer possibilities of methods and techniques, the necessity has arisen to regulate them in ways that are individually adapted to particular sites. Regulations and bans on climbing should include not only sites of particular values and those that are legally protected, but also other rocky forms with low resistance to this type of use. Natural outcrops of sandstones showing a diversity of sedimentary structures and forms of weathering exposed on the rock surface by selective weathering are particularly popular sites for bouldering. These structures and forms are both convenient and safe points along the routes for negotiating the height of walls.

Destructive changes in weathering micro-forms on the exposed surfaces, being the consequences of climbing, are found in various regions of the world whenever rock landscapes occur. Unfortunately, they do not encounter strong opposition. At the same time, ever more numerous local climbing clubs are organized which illegally develop their activities that are also, and sometimes exclusively, in areas protected by regional, state, or even international laws. The protection of the natural character of elements of nature and landscape has, after all, to serve the whole of society, and not to satisfy the individual needs of certain small groups of people.

Climbing activities should first be completely eliminated from areas where rock objects are a primary objective of protection. They should be attributed by regulations, scientific and didactic functions, as well as ensure properly controlled tourism. Any other kind of use of these sites definitely exerts a negative educational effect on visitors, particularly on young people, giving them permission for such improper conduct. Climbing can be exercised with full emotional satisfaction on artificial walls, especially those which are formed to mimic natural rocks. These are safer and more accessible than natural forms sometimes situated (e.g., in the Carpathians) in places that are far from centres of tourism.

Any activity causing the destruction of exceptional rocky outcrops and areas with natural landscapes regardless of their object and the protection status is unethical (Martinez-Frias et al., 2011; Druguet et al., 2013; Matteucci et al., 2014). When harming and destroying the morphology of rock surfaces shaped by natural processes, it becomes one of many signs of vandalism. Such activities show a lack of sensitivity to the surrounding nature and landscape, as well as a lack of awareness of the consequences of such conduct, generally stemming from a lack of knowledge of geological history and processes going on Earth. A widespread education on many thematic levels can successively contribute to positive changes more effectively than difficult-to-enforce bans. Geoethical education, promoted in the sphere of principles of proper conduct, should cover a wide spectrum of present and predicted anthropogenic threats to the values of geological heritage. Current threats to it come not only from activities consisting of drilling holes for taking samples, considered part of " $A$ Code of Conduct for Rock Coring” (Robinson, 1989). Equal attention should be paid to the similarly damaging role of unethical rock climbing activities and careless graffiti, which are especially fashionable activities among certain groups of young people. Geoethical education is a constructive foundation for implementing all types of activities aimed at protecting our geological heritage.

\section{Acknowledgements}

The author would like to thank anonymous Reviewers, whose comments and suggestions greatly improved the manuscript and Dr. Fareeduddin for the editorial management of the article.

\section{References}

Adamovič, J., Mikuláš, R., and Cílek, V., 2006, Sandstone districts of the Bohemian Paradise: Emergence of the romantic landscape: Academy of Sciences of the Czech Republic, Prague, GeoLines, v.21, 100 p.

Alexandrowicz, Z., 1970, Skałki piaskowcowe w okolicy Ciężkowic nad Białą (Sandstone rocks in the vicinity of Ciężkowice on the Biała river): Ochrona Przyrody, v.35, pp. 281-335. (in Polish with English summary)

Alexandrowicz, Z., 1977, The origin of sandstone tors in the Polish Western Carpathians: Bulletin of the Polish Academy of Sciences, Earth Series, v.25, no.2, pp. 83-90.

Alexandrowicz, Z., 1978, Skałki piaskowcowe zachodnich Karpat fliszowych 
(Sandstone tors of the Western Flysch Carpathians). Prace Geologiczne Komisji Nauk Geologicznych PAN Oddział Kraków, v.113, 87 p. (in Polish with English summary)

Alexandrowicz, Z., 1989, Evolution of weathering pits on sandstone tors in the Polish Carpathians: Zeitschrift für Geomorphologie N.F., v.33, no.3, pp. 275-289.

Alexandrowicz, Z., 2008, Sandstone rocky forms in the Polish Carpathians attractive for education and tourism: Przegląd Geologiczny, v.56, no.8/1, pp. 680-687.

Alexandrowicz, Z., 2014, Kamienie Brodzińskiego na Pogórzu Wiśnickim problem zagrożenia karpackich skałek piaskowcowych działalnością wspinaczkową (Brodziński Stones on the Wiśnicz Foothill - a problem of the Carpathian sandstone tors at risk from rock climbing): Chrońmy Przyrodę Ojczystą, v.70, no.1, pp. 3-18. (in Polish with English summary)

Alexandrowicz, Z., and Brzeźniak, E, 1989, Uwarunkowanie procesów wietrzenia na powierzchni skałek piaskowcowych w wyniku zmian termiczno-wilgotnościowych w Karpatach fliszowych (Dependences of weathering processes on surface sandstone rocks as a result of thermohumidity changes in the Flysch Carpathians): Folia Geographica, Series Geographica-Physica, v.21, pp. 17-36. (in Polish with English summary)

Alexandrowicz, Z., and Margielewski, W., 2010, Impact of mass movements on geo- and biodiversity in the Polish Outer (Flysch) Carpathians: Geomorphology, v.123, pp. 290-304.

Alexandrowicz, Z., and Pawlikowski, M., 1982, Mineral crusts on the surface weathering zone of sandstone tors in the Polish Carpathians: Mineralogia Polonica, v.13, no.2, pp. 41-59.

Alexandrowicz, Z., and Poprawa D. (eds.), 2000, Ochrona georóżnorodności w Polskich Karpatach (Geodiversity conservation in the Polish Carpathians): Państwowy Instytut Geologiczny, Warszawa, 142 p. (in Polish with English summary)

Alexandrowicz, Z., Marszałek, M., and Rzepa, G., 2012, Rola kory wietrzeniowej w ewolucji powierzchni karpackich skałek piaskowcowych (The role of weathering crust in the evolution of surfaces on the Carpathian sandstone tors): Chrońmy Przyrodę Ojczystą, v.68, no.3, pp. 163-174. (in Polish with English summary)

Alexandrowicz, Z., Marszałek, M., and Rzepa, G., 2014, Distribution of secondary minerals in crusts developed on sandstone exposures:Earth Surface Processes and Landforms, v.39, pp. 320-335.

Alexandrowicz, Z., and Urban, J., 2005, Sandstones regions of Poland. Geomorphological types, scientific importance and problems of protection, in Ries, C., and Krippel, Y., eds., Sandstone, Landscapes in Europe, Past, Present and Future. Ferrantia, v.44, pp. 137-141.

Baumgart-Kotarba, M., 1974, Rozwój grzbietów górskich w Karpatach fliszowych (Developmentof mountain ridges in the flysch Carpathians): Prace Geograficzne Instytutu Geografii PAN, Warszawa, v.106, 136 p. (in Polish with English summary)

Bromowicz, J., Gucik, S., Magiera, J., Moroz-Kopczyńska, M., Nowak, T.W., and Peszat, C., 1976, Piaskowce karpackie, ich znaczenie surowcowe i perspektywy wykorzystania (The Carpathian sandstones, their significance as raw materiale and perspectives of their utilization): Zeszyty Naukowe AGH, Geologia, v.2, no.2, pp. 1-95. (in Polish with English summary)

Čeřovský, J., 2007, Sandstone Switzerlands, paradises and landmarks: the development and present status of nature and landscape protection in the sandstone areas of Europe, in Härtel, H., Cílek, V., Herben, T., Jackson, A., and Williams, R., eds., Sandstone Landscapes, Academia, Praha, pp. 300-306.

Cílek, V., 1997, Sandstone phenomenon: antagonism between surface hardening and salt weathering: Folia Faculty Sciences Nature, University in Brno, Geologia, v.39, pp. 33-38.

Dikau, R., Brunsden, D., Schrott, L., and Ibsen, M.I. (eds.), 1996, Landslide, recognition, identification movement and causes: John Wiley \& Sons, Chichester, $251 \mathrm{p}$.
Druguet, E., Passchier, C.W., Pannacchioni G., and Carreras, J., 2013, Geoethical education: A critical issue for geoconservation: Episodes, v.36, no.1, pp. 11-18.

Giuliano, W., 1994, The impact of hiking and rock climbing in mountain areas: Environmental Conservation, v.21, pp. 278-279.

Goudie, A.S., and Viles, H., 2008, Weathering processes and Forms, in Burt, T.P., Chorley, R.J., Brunsden, D., Cox, N.J., and Goudie, A.S., eds., Quaternary and Recent Processes and Forms. Geological Society, pp. 129-164.

Hall, K., 1997, Rock temperatures and implications for cold region weathering. I: New data from Viking Valley, Alexander Island, Antarctica: Permafrost Periglacial Processes, v.8, pp. 69-90.

Jodłowski, M., 2011, Zasady dobrej praktyki w zarządzaniu ruchem wspinaczkowym na obszarach chronionych (Good- practice manual of climbing management in protected areas): Instytut Geografii i Gospodarki Przestrzennej, Uniwersytet Jagielloński, Kraków, 208 p. (in Polish with English summary)

Kicińska, A., 2009, Struktury komórkowe w obrębie piaskowców magurskich na przykładzie Diabelskich Ścian (pasmo Jaworzyny Krynickiej (Cellular structures in the Magura sandstones - an example from the Devil's Wall in the Jaworzyna Krynicka Range): Geologia, v.35, no.2, pp. 201-214. (in Polish with English summary)

Klimaszewski, M., 1932, "Grzyby skalne” na pogórzu karpackim między Rabą a Dunajcem (Mushroomshaped rocks in the sub-Carpathian hills): Ochrona Przyrody, v.12, pp. 64-70. (in Polish with English summary)

Klimaszewski, M., 1947, Osobliwości skalne w Beskidach Zachodnich: Wierchy, v.17, pp. 57-71. (in Polish)

Koszarski, L., 1962, Skałki piaskowców istebniańskich w okolicy Krosna (The rocks of the Istebna sandstones in the vicinity of Krosno, Flysch Carpathians): Chrońmy Przyrodę Ojczystą, v.17, no.6, pp. 17-31. (in Polish with English summary)

Książkiewicz, M., 1972, Karpaty (Carpathians), in Pożaryski, W., ed., Budowa geologiczna Polski (Geological structure of Poland), vol. 4, Tektonika (Tectonics), part 3, Wydawnictwa Geologiczne, Warszawa, 228 p. (in Polish)

Lach, J., 1970, Fazy rozwoju form skalnych w Magurze Wątkowskiej (Rock measures in the Magurian at Wątków and their phases of development): Rocznik Naukowo-Dydaktyczny WSP w Krakowie, Geografia, v.5, pp. 24-33. (in Polish with English summary)

Leszczyński, S., 1989, Characteristics and origin of fluxoturbidites from the Carpathian flysch (Cretaceous Palaeogene), South Poland: Annales Societatis Geologorum Poloniae, v.59, pp. 351-390.

Lewkowicz, A.G., 2001, Temperature regime of a small sandstone tor, latitude $80^{\circ} \mathrm{N}$, Ellesmere Island, Nunavut, Canada: Permafrost and Periglacial Processes v.12, pp. 351-366.

Margielewski, W., 2006, Structural control and types of movements of rock mass in anisotropic rocks: case studies in the Polish Flysch Carpathians: Geomorphology, v.77, pp. 47-68.

Marszałek, M., Alexandrowicz, Z., and Rzepa, G., 2014, Composition of weathering crusts on sandstones from natural outcrops and architectonic elements in the urban environment: Environmental Science and Pollution Research, v.21, pp. 14023-14036.

Marszałek, M., Rzepa, G., and Alexandrowicz, Z., 2012, Mineralogical characteristics of weathering crust on the Polish Flysch Carapthian sandstones: Acta Mineralogica-Petrographica, Abstract Series, Szeged, v.7, p. 84 .

Martinez-Frias, J., Gonzales Garcia, J.L., and Rull, F., 2011, Geoethics and Deontology: From fundamentals to applications in Planetary Protection: Episodes, v.34, no.4, pp. 257-262.

Matteucci, R., Gosso, G., Peppoloni, S., Piacente S., and Wasowski, J., 2014, The "Geoethical Promise": A Proposal: Episodes, v.37, no.3, pp. 190-191.

Mikuláš, R., 2007a, The concept of porokrast: sandstone sculpturing across climatic zones and lithofacies, in Härtel, H., Cílek, V., Herben, T., Jackson, A., and Williams, R., eds., Sandstone Landscapes, Academia, Praha, 
pp. 79-82.

Mikuláš, R., 2007b, Microforms of the sandstone relief, in Härtel, H., Cílek, V., Herben, T., Jackson, A., and Williams, R., eds., Sandstone Landscapes, Academia, Praha, pp. 66-75.

Moses, C., Robinson, D., and Barlow, J., 2014, Methodes for measuring rock surface weathering and erosion: A critical review: Earth Science Reviews, v.135, pp. 141-161.

Mustoe, G.E., 1982, The origin of honeycomb weathering: Geological Society of America Bulletin, v.93, no.2, pp. 108-115.

Oszczypko, N., 2006, Late Jurassic-Miocene evolution of the Outer Carpathians fold-and-trast belt and its foredeep basin (Western Carpathians): Geological Quarterly, v.50, no.1, pp. 169-194.

Robinson, E., 1989, For geologists: A code of cConduct for rock-coring: Environmental Conservation, v.16, pp. 370-371.

Robinson, D.A., 2007, Geomorphology of the inland sandstone cliffs of Southeast England, in Härtel, H., Cílek, V., Herben, T., Jackson, A., and Williams, R., eds., Sandstone Landscapes, Academia, Praha, pp. 44-51.

Robinson, D.A., and Williams, R.B.G., 1994, Rock weathering and Landform Evolution: Wiley, Chichester, 544 p.

Robinson, D.A., and Williams, R.B.G., 2005, Comparative morphology and weathering characteristics of sandstone outcrops in England, UK, in Ries, C., and Krippel, Y., eds., Sandstone, Landscapes in Europe, Past, Present and Future. Ferrantia, v.44, pp. 41-45.

Rzepa, G., Marszałek, M., and Alexandrowicz, Z., 2011, Application of sequential chemical extractions and Mőssbauer spetroscopy for indentification of iron distribution in the weathering crust on the Flysch Carpathian's sandstones: Mineralogia Specical Paper, v.38, pp. 160-162.

Strzeboński, P., 2009, Piaskowcowo-zlepieńcowe formy skałkowe - więcej niż atrakcja turystyczna (Sandstone-conglomerate rocky forms - more than a tourist attraction): Geoturystyka, v.1-2, nos.16-17, pp. 49-60. (in Polish with English summary)

Ślączka A., and Thompson III, S., 1981, A revision on the fluxoturbidite concept based on type examples in Polish Carpathian Flysch: Annales Societatis Geologorum Poloniae, v.51, pp. 3-4.

Świdziński, H., 1933, "Prządki" - skałki piaskowca ciężkowickiego pod Krosnem ("Prządki" - groupe de rochers près de Krosno, Karpates): Zabytki Przyrody Nieożywionej, v.2, pp. 94-125. (in Polish with French summary)

Turkington, A.V., and Paradise, T.R., 2005, Sandstone weathering: a century of research and innovation: Geomorphology, v.67, pp. 229-253.

Unrug, R., 1963, Istebna beds - a fluxoturbidity formation in the Carpathian Flysch: Rocznik Polskiego Towarzystwa Geologicznego, v.33, no.1, pp. 51-92.

Wilczyńska-Michalik, W., 2004, Influence of atmospheric pollution on the weathering of stones in Cracow monuments and rock outcrops in Cracow, Cracow-Częstochowa Upland and the Carpathians. Prace Monograficzne, no. 377: Akademia Pedagogiczna, Kraków, 247 p.

Williams, R., 2007, Visitor damage at sandstone outcrops in Southeast England, in Härtel, H., Cílek, V., Herben, T., Jackson, A., and Williams, R., eds., Sandstone Landscapes, Academia, Praha, pp. 307-314.

Williams, R.B.G., Swantesson, J.O.H., and Robinson D.A., 2000, Messuring rates of surface downwearing and mapping microtopography: The use of micro-erosion meters and lasers scanners in the rock weathering studies: Zeitschrift für Geomorphologie N.F., v.120, pp. 51-66.

Wilhelmy, H., 1958, Klimamorphologie der Massengesteine: Georg Westermann, Verlag, Braunschweig, $238 \mathrm{p}$.

Wiśniewski, E., 1983, Bunger Oasis: the largest ice-free area in the Antarctic: Terra, v.95, no.3, pp. 178-187.

Żytko, K., Zając, R., Gucik, S., Ryłko, W., Oszczypko, N., Garlicka, I., Nemčok, j., Eliáš, M., Menčik, E., and Stránik, Z., 1988-1989, Map of the tectonic elements of the Western Outer Carpathians and their Foreland, in Poprawa, D., and Nemčok, J., eds., Geological Atlas of the Western Outer Carpathians and their Foreland, PIG Warszawa, GUDS Bratislava, UUG Praha.

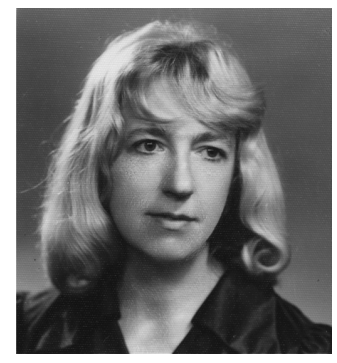

Zofia Alexandrowicz is a professor at the Institute of Nature Conservation, Polish Academy of Sciences in Krakow, Poland. She is a geologist with scientific interests focused mainly on the origin and geological setting of rock landforms and their relief controlled by weathering and erosion processes. She is one of the chartered members of the European Association for the Conservation of Geological Heritage (ProGeo), and has organized, and led for a long time, the Working Group of Central Europe. She is the author of numerous publications concerning rock landforms, frameworks of geosites, educational training and the history of geoconservation. 